\title{
Morphogenesis of Torrent Beds in the Watersheds with a Different Geological Bedrock and Geomorphological Rock Value
}

\author{
Matúš Jakubis ${ }^{1 *}$, Mariana Jakubisová \\ 1 Department of Forest Harvesting, Logistics and Amelioration, Faculty of Forestry, Technical University in \\ Zvolen, 96053 Zvolen, Slovak Republic \\ 2 The Borova Hora Arboretum of the Technical University in Zvolen, 96053 Zvolen, Slovak Republic \\ * Corresponding author's e-mail: jakubis@tuzvo.sk
}

\begin{abstract}
The paper deals with the morphogenesis of natural torrent beds in two watersheds with different geological backgrounds and a different geomorphological rock value: Hučava (geomorphological unit of Pol'ana with geological bedrock: neovulcanites - pyroxene and hornblende-pyroxene andesites, andesite porphyry, rhyolites, rhyodacites, rhyolite tuffs, diorite porphyry) and Mútňanka (geomorphological units of Podbeskydská brázda and Oravské Beskydy with geological bedrock: flysh - claystones, sandstones, shales-thin bedded flysh, microconglomerates). The bankfull geometric characteristics of a natural reference cross-sections of these torrents: the width of the channel inside the banks $\mathrm{W}_{\text {bkf }}(\mathrm{m})$, mean channel depth $\mathrm{D}_{\mathrm{bkf}}(\mathrm{m})$, channel cross-section area $\mathrm{A}_{\mathrm{bkf}}\left(\mathrm{m}^{2}\right)$ and the hydraulic characteristic, namely bankfull discharge $Q_{b k f}\left(\mathrm{~m}^{3} \cdot \mathrm{s}^{-1}\right)$ in relation to the watershed area $A_{w}\left(\mathrm{~km}^{2}\right)$, were analyzed and compared. The analyses showed a strong correlation between the watershed area $\mathrm{A}_{\mathrm{w}}\left(\mathrm{km}^{2}\right)$ and the bankfull geometric characteristics of natural cross-sections: $\mathrm{W}_{\mathrm{bkf}}(\mathrm{m}), \mathrm{D}_{\mathrm{bkf}}(\mathrm{m}), \mathrm{A}_{\mathrm{bkf}}\left(\mathrm{m}^{2}\right)$ and the hydraulic characteristic $\mathrm{Q}_{\mathrm{bkf}}\left(\mathrm{m}^{3} \cdot \mathrm{s}^{-1}\right)$. In the analyzed relationships, the coefficient of determination $\left(\mathrm{R}^{2}\right)$ ranged from $\mathrm{R}^{2}=0.905$ to $\mathrm{R}^{2}=0.962$ in the Hučava torrent and between $\mathrm{R}^{2}=0.912$ to $\mathrm{R}^{2}=0.958$ for the torrent of Mútňanka. Using statistical testing, the significance of the differences between the absolute and as well as regression coeficients in the hydraulic geometry equations for these torrents and their watersheds of different geological bedrock were confirmed.
\end{abstract}

Keywords: rock resistance, regional hydraulic geometry, watercourse channel characteristics

\section{INTRODUCTION}

The morphogenesis of watercourse beds has been a longstanding interest of the scientists around the world dealing with many related problems within various scientific fields (geomorphology, fluvial morphology, river regulation, torrent control, landscape management etc.). The researchers focused on a wide range of related issues. The issue of watercourses regional hydraulic geometry is one of them. [Blackburn-Lynch et al., 2017] mention the following basic regional hydraulic geometry equations:

$$
\begin{aligned}
\mathrm{W}_{\mathrm{bkf}} & =\mathrm{aA}_{\mathrm{w}}{ }^{\mathrm{b}} \\
\mathrm{D}_{\mathrm{bkf}} & =\mathrm{cA}_{\mathrm{w}}{ }^{\mathrm{d}} \\
\mathrm{A}_{\mathrm{bkf}} & =\mathrm{eA}_{\mathrm{w}}{ }^{\mathrm{f}}
\end{aligned}
$$

$$
\mathrm{Q}_{\mathrm{bkf}}=\mathrm{gA}_{\mathrm{w}}{ }^{\mathrm{h}}
$$

where: $W_{b k f}-$ the width of the channel inside the banks (m), $D_{b k f}$ - mean channel depth (m), $A_{b k f}\left(\mathrm{~m}^{2}\right)$ - channel cross-section area, $Q_{b k f}\left(\mathrm{~m}^{3} \cdot \mathrm{s}^{-1}\right)$ - bankfull discharge, $A_{w}\left(\mathrm{~km}^{2}\right)$ - the watershed area.

The morphogenesis (long-term development) of watercourse beds varies, depending on different geological conditions of the watersheds. Authors [Wolock et al., 2004] divided the USA into 20 Hydrologic Landscape Regions (HLRs) on the basis of similar natural characteristics of watersheds. [Bieger et al., 2015, Blackburn-Lynch et al., 2017] confirmed a diverse nature of regional regression equation coefficients for equations 
(1) to (4), describing different HLRs. Another author [Pšida, 2014] evaluated the relationships of bankfull regional hydraulic geometry in four geographic regions - geomorphologic units in the SR with different bedrocks. The author confirmed different development of the torrent beds under different geological conditions. The geological (rock) resistance or geomorphological rock value expresses the resistance of rocks to erosion and depends mainly on their hardness, cohesion and chemical reactivity. Notable papers and books on this issue were published by such authors as [Leopold et al., 1995, Montgomery and Buffington, 1997, Wohl, 1998, Tinkler and Wohl, 1998, Radecki-Pawlik, 2002, 2014, Vianello and D'Agostino, 2007, Charlton, 2008, Galia and Hradecký, 2014, Gleason, 2015, Roviński and Radecki-Pawlik, 2016]. Abroad, the term of geomorphological value is often used in the context of natural heritage and the natural value of the landscape [Dobos and Gali, 2010, Badman, 2010, Weiyan et al., 2013, Costa-Casais et al., 2015, Reynard and Brilha, 2018 etc.]. Moreover, the resistance of rocks or geological structures is called durability of rocks or rock durability [Lindqvist et al., 2003, Franke, 2018]. [Sládek, 2014] notes that the geomorphological rock value is a fundamental concept in geomorphology and this term has been widely adopted in the respective literature. This author proposes three degree of rocks resistance: (i) Highly resistant rocks (very hard rocks), (ii) Moderately resistant rocks and (iii) Less resistant rocks. For the territory of the SR, author [Valtýni, 1981] created five basic regions according to the resistance of the bedrock and the hydrologic efficiency. The neovolcanites (andesites, rhyolites, andesite porphyry, rhyolites, rhyodacites, rhyolite tuffs) rank among the highly resistant rocks. The author classified flysh (claystones, sandstones, shales-thin bedded flysh, microconglomerates) as occupying the position between moderately resistant and less resistant rocks. Important information on the issue was compiled in detail by [Sládek, 2014]. [Lacika, 1999] divided rocks into three groups by their origin: magmatic rocks, sedimentary rocks and metamorphic rocks and he also proposed three groups of classification by resistance. Andesites and rhyolites rank among highly resistant rocks; sandstones, claystones and conglomerates among moderately resistant rocks. Another author [Dzurovčin, 2000] prepared a table of rocks resistance table in a temperate continental climate according to [Klimaszewski, 1981]. According to the authors, the porphyry display great mechanical resistance; the sandstones - small to medium mechanical resistance and shales - even low mechanical resistance. [Michaeli, 2001] also ranked andesites among the highly resistant rocks from the three rock resistance groups; the sandstones, claystones and conglomerates ranked among the moderately resistant rocks. According to [Marko et al., 2007], the andesites and rhyolites rank as highly resistant rocks; sandstones and conglomerates as moderately resistant rocks. The geomorphological rock value affects the torrent bed development concurrently with the hydrological efficiency of geological bedrock. Hydrological rock efficiency means the ability of rocks to retain water in the watershed. High hydrological efficiency of the geological bedrock generally means lower surface runoff and vice versa.

\section{MATERIALS AND METHODS}

For the purpose of research, we selected two watersheds (Fig. 1) with a different geological bedrock (Table 1): Hučava in the geomorphological unit of Pol'ana with a geological bedrock: neovulcanites - pyroxene and hornblende-pyroxene andesites, andesite porphyry, rhyolites, rhyodacites, rhyolite tuffs, diorite porphyry and Mútňanka in the geomorphological units of Podbeskydská brázda and Oravské Beskydy, with a geological bedrock: flysh - claystones, sandstones, shales-thin bedded flysh, microconglomerates [Composite Authors, 2002].

Morphological characteristics of experimental watersheds and torrents are listed in Tables 2 and 3.

On straight stretches of both torrents, we selected the reference longitudinal sections (RLS) with reference cross-sections (RCS) and determined their geometric and hydraulic characteristics according to [Page, 1988, Rosgen and Silvey, 1996, Rosgen, 2009]. We estabilished RLS and RCS in the terrain under the torrents sediments source zones in natural sections without direct human intervention. We determined the geometric characteristics of the RCS by leveling. The measured and calculated geometric characteristics of reference cross-sections are as follows: width of the channel inside the banks $\mathrm{W}_{\mathrm{bkf}}(\mathrm{m})$, mean channel depth $\mathrm{D}_{\mathrm{bkf}}(\mathrm{m})$, reference cross-sectional area $\mathrm{A}_{\mathrm{bkf}}\left(\mathrm{m}^{2}\right)$ and the hydraulic characteristic: bankfull discharge $\mathrm{Q}_{\mathrm{bkf}}\left(\mathrm{m}^{3} . \mathrm{s}^{-1}\right)$ for torrent Hučava with the medians of $\mathrm{W}_{\mathrm{bkf}}=8.10(\mathrm{~m}), \mathrm{D}_{\mathrm{bkf}}=1.00(\mathrm{~m})$, 


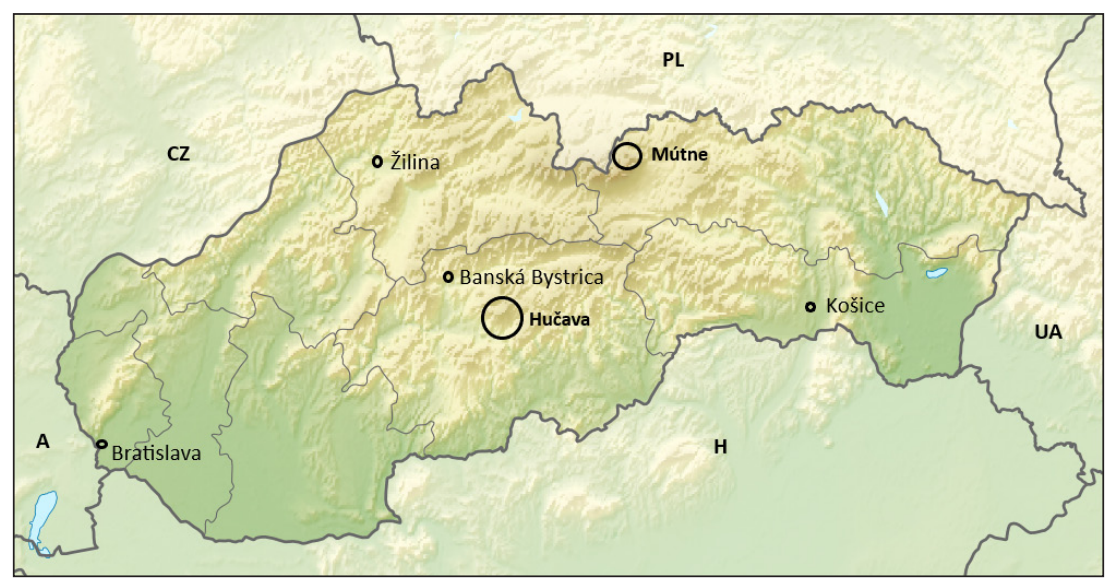

Figure 1. Map of Slovakia with the research areas

Table 1. Geological bedrock in watersheds of analyzed torrents

\begin{tabular}{|c|l|}
\hline Watershed & \multicolumn{1}{|c|}{ Geological bedrock } \\
\hline Hučava & $\begin{array}{l}\text { Pyroxene and hornblende-pyroxene andesites, andesite porphyry, rhyolites, rhyodacites, rhyolite tuffs, } \\
\text { diorite porphyry }\end{array}$ \\
\hline Mútňanka & Claystones, sandstones, shales-thin bedded flysh, microconglomerates \\
\hline
\end{tabular}

Table 2. Basic characteristics of watersheds (part 1)

\begin{tabular}{|c|c|c|c|c|c|c|c|c|c|}
\hline Torrent & $\begin{array}{c}\mathrm{A}_{\mathrm{w}} \\
\left(\mathrm{km}^{2}\right)\end{array}$ & $\begin{array}{c}\mathrm{H}_{\text {minw }} \\
(\mathrm{m} \text { a.s.I. })\end{array}$ & $\begin{array}{c}\mathrm{H}_{\operatorname{maxw}} \\
(\mathrm{m} \text { a.s.I. })\end{array}$ & $\begin{array}{c}\Delta \mathrm{H}_{\mathrm{w}} \\
(\mathrm{m})\end{array}$ & $\begin{array}{c}\mathrm{H}_{\text {ow }} \\
(\mathrm{m} \text { a.s.I. })\end{array}$ & $\begin{array}{c}\mathrm{L}_{\mathrm{tr}} \\
(\mathrm{km})\end{array}$ & $\begin{array}{c}\mathrm{L} \\
(\mathrm{km})\end{array}$ & $\begin{array}{c}\mathrm{L}_{\mathrm{t}} \\
(\mathrm{km})\end{array}$ & $\begin{array}{c}\mathrm{L}_{\mathrm{v}} \\
(\mathrm{km})\end{array}$ \\
\hline Hučava & 41.16 & 523 & 1457 & 934 & 929 & 33.626 & 14.198 & 47.824 & 14.516 \\
\hline Mútňanka & 29.93 & 789 & 1556 & 767 & 1008 & 38.894 & 8.370 & 47.264 & 8.855 \\
\hline
\end{tabular}

Explanatory notes to Table 2: $\mathrm{A}_{\mathrm{w}}$ - watershed area $\left(\mathrm{km}^{2}\right) ; \mathrm{H}_{\text {minw }}$ - minimal altitude in the watershed (m a.s.l.); $\mathrm{H}_{\text {maxw }}$ - maximal altitude in the watershed (m a.s.l.); $\Delta \mathrm{H}_{\mathrm{w}}-$ absolute height difference of the watershed; $\mathrm{H}_{\varnothing \mathrm{w}}-$ mean altitude of the watershed (m a.s.1.); $\mathrm{L}_{\mathrm{tr}}$ - total length of tributaries $(\mathrm{km}) ; \mathrm{L}$ - length of main stream $(\mathrm{km}) ; \mathrm{L}_{\mathrm{t}}-$ total length of watercourses in the watershed $(\mathrm{km}) ; \mathrm{L}_{\mathrm{v}}-$ length of torrent valley $(\mathrm{km})$.

Table 3. Basic characteristics of watersheds (part 2)

\begin{tabular}{|c|c|c|c|c|c|c|c|c|c|}
\hline Torrent & $\begin{array}{c}\mathrm{H}_{\text {mint }} \\
(\mathrm{m} \text { a.s.I. })\end{array}$ & $\begin{array}{c}\mathrm{H}_{\operatorname{maxt}} \\
(\mathrm{m} \text { a.s.l. })\end{array}$ & $\begin{array}{c}\Delta \mathrm{H}_{\mathrm{t}} \\
(\mathrm{m})\end{array}$ & $\begin{array}{c}\mathrm{A}_{\mathrm{f}} \\
\left(\mathrm{km}^{2}\right)\end{array}$ & $\begin{array}{c}\mathrm{L}_{\mathrm{d}} \\
(\mathrm{km})\end{array}$ & $\begin{array}{c}\mathrm{S}_{\phi t} \\
(\%)\end{array}$ & $\begin{array}{c}\mathrm{S}_{\rho \mathrm{w}} \\
(\%)\end{array}$ & $\begin{array}{c}\mathrm{B}_{\mathrm{w}} \\
(\mathrm{km})\end{array}$ & $\begin{array}{c}\mathrm{w}_{\mathrm{w}} \cdot \mathrm{l}_{\mathrm{w}} \\
(-)\end{array}$ \\
\hline Hučava & 523 & 1328 & 805 & 34.831 & 43.340 & 5.67 & 32.48 & 2.835 & $1: 5.12$ \\
\hline Mútňanka & 789 & 1251 & 462 & 26.456 & 31.080 & 5.52 & 23.80 & 3.380 & $1: 2.62$ \\
\hline
\end{tabular}

Explanatory notes to Table $3: \mathrm{H}_{\text {mint }}$ - maximal altitude of the torrent (m a.s.l.); $\mathrm{H}_{\text {maxt }}$ - maximal altitude of the torrent - source (m a.s.l.); $\Delta \mathrm{H}_{\mathrm{t}}$ - absolute torrent height difference $(\mathrm{m}) ; \mathrm{A}_{\mathrm{f}}-$ forested watershed area $\left(\mathrm{km}^{2}\right) ; \mathrm{L}_{\mathrm{d}}-$ legth of the divide $(\mathrm{km}) ; \mathrm{S}_{\varnothing \mathrm{t}}-$ mean gradient of the torrent $(\%) ; \mathrm{S}_{ø \mathrm{w}}-$ mean slopes gradient of the watershed $(\%)$; $\mathrm{B}_{\mathrm{w}}-$ mean width $(\mathrm{km}) ; \mathrm{w}_{\mathrm{w}}: \ell_{\mathrm{w}}-$ width/lenght ratio of the watershed (-).

$\mathrm{A}_{\mathrm{bkf}}=6.40\left(\mathrm{~m}^{2}\right)$ and $\mathrm{Q}_{\mathrm{bkf}}=16.12\left(\mathrm{~m}^{3} \cdot \mathrm{s}^{-1}\right)$ are listed in Table 4 and for torrent Mútne with medians of $\mathrm{W}_{\mathrm{bkf}}=6.20(\mathrm{~m}), \mathrm{D}_{\mathrm{bkf}}=0.65(\mathrm{~m}), \mathrm{A}_{\mathrm{bkf}}=2.98$ $\left(\mathrm{m}^{2}\right)$ and $\mathrm{Q}_{\mathrm{bkf}}=5.29\left(\mathrm{~m}^{3} \cdot \mathrm{s}^{-1}\right)$ are listed in Table 5. The longitudinal slope S (\%) of RLS was calculated from the RLS altitude differences estabilished by their leveling with the median for the torrent Hučava of $\mathrm{S}=1.65(\%)$ and Mútňanka
$\mathrm{S}=1.84(\%)$. More than fifty kilogram of sediment samples were collected on each RCS in order to conduct of sieve granulometric analyses used to determine the grain diameter $\mathrm{D}_{50}(\mathrm{~m})$ with the medians of Hučava $\mathrm{D}_{50}=0.125(\mathrm{~m})$ and Mútňanka $\mathrm{D}_{50}=0.169(\mathrm{~m})$. We also determined the hydraulic radius $R_{b k f}(m)$ with the medians of Hučava $\mathrm{R}_{\mathrm{bkf}}=0.716(\mathrm{~m})$ and Mútňanka 
$\mathrm{R}_{\mathrm{bkf}}=0.446(\mathrm{~m})$ during the office-run processing. Watersheds areas with up to the RCS as enclosing profiles were from the maps with GIS methods determined with median of $\mathrm{A}_{\mathrm{w}}=31.99 \mathrm{~km}^{2}$ (Hučava) and $6.10 \mathrm{~km}^{2}$ (Mútne). In orde to calculate the bankfull discharge $\mathrm{Q}_{\mathrm{bf}}\left(\mathrm{m}^{3} . \mathrm{s}^{-1}\right)$, we used the equation according to [Parker, 2004]:

$$
\begin{gathered}
Q_{b f}=3.732 W_{b k f} D_{b k f} \sqrt{g R_{b k f} S}\left(\frac{R_{b k f}}{D_{50}}\right)^{0.2645} \\
\left(m^{3} s^{-1}\right)
\end{gathered}
$$

We used the following regression equation for the analysis:

$$
\mathrm{y}=\mathrm{a}_{0} \cdot \mathrm{x}^{\mathrm{a} 1}
$$

\section{RESULTS AND DISCUSSION}

The geometric and hydraulic characteristics of RCS of both torrents are shown in Tables 4 and 5 . The analyses showed a strong correlation between the watershed area $\mathrm{A}_{\mathrm{w}}\left(\mathrm{km}^{2}\right)$ and the bankfull geometric characteristics of natural cross-sections: the width of the bed inside the banks $\mathrm{W}_{\mathrm{bkf}}(\mathrm{m})$, mean depth of the bed $D_{b k f}(m)$, the channel cross-section area $A_{b k f}\left(\mathrm{~m}^{2}\right)$ and the hydraulic characteristic - bankfull discharge $\mathrm{Q}_{\mathrm{bkf}}\left(\mathrm{m}^{3} \cdot \mathrm{s}^{-1}\right)$. The regression equations of the relationships are shown in Table 6 . In the analyzed relationships, the coefficient of determination $\left(\mathrm{R}^{2}\right)$ ranged from $\mathrm{R}^{2}=0.905$ to $\mathrm{R}^{2}$ $=0.962$ in the Hučava torrent and between $\mathrm{R}^{2}=$ 0.912 and $\mathrm{R}^{2}=0.958$ for the torrent of Mútňanka (Tab.7). Subsequently, the differences between the absolute and relative coefficients in regression equations for torrents Hučava and Mútňanka were statistically tested and their statistical significance was confirmed (Table 8). The statistical significance of the differences was not confirmed only by evaluating of relative coefficients $\mathrm{a}_{1}$ in the relation $\mathrm{Q}_{\mathrm{bkf}}=\mathrm{f}\left(\mathrm{A}_{\mathrm{w}}\right)$ for both watersheds. Figures (2) to (5) show the graphical representation of each relationship, making it clear that the development of the geometric characteristics of the bed and also the bankfull discharge in relation to the watershed area $A_{w}\left(\mathrm{~km}^{2}\right)$ is significantly different. The torrent bed of Mútňanka, developed in the flysh geological bedrock with a lower geomorphological rock value (rock resistance), has - in

Table 4. Geometric and hydraulic characteristics of RCS - Hučava

\begin{tabular}{|c|c|c|c|c|c|c|c|c|c|}
\hline No. RCS & $\mathrm{A}_{\mathrm{w}}$ & $\mathrm{H}_{\mathrm{w}}$ & $\mathrm{W}_{\text {bkf }}$ & $\mathrm{D}_{\text {bkf }}$ & $\mathrm{A}_{\text {bkf }}$ & $\mathrm{R}_{\text {bkf }}$ & $\mathrm{S}$ & $\mathrm{D}_{50}$ & $\mathrm{Q}_{\text {bkf }}$ \\
\hline 1 & 41.16 & 523 & 10.3 & 1.15 & 9.4 & 0.847 & 1.03 & 0.090 & 23.45 \\
\hline 2 & 39.05 & 554 & 9.9 & 1.15 & 9.1 & 0.843 & 1.10 & 0.112 & 21.94 \\
\hline 3 & 38.15 & 568 & 9.7 & 1.1 & 8.8 & 0.846 & 0.92 & 0.115 & 18.68 \\
\hline 4 & 37.58 & 575 & 9 & 1 & 8 & 0.784 & 1.30 & 0.110 & 17.83 \\
\hline 5 & 37.31 & 582 & 8.8 & 1.05 & 7.7 & 0.762 & 1.39 & 0.120 & 18.10 \\
\hline 6 & 36.65 & 602 & 8.7 & 1 & 7.3 & 0.753 & 1.57 & 0.117 & 18.11 \\
\hline 7 & 36.09 & 620 & 8.7 & 1.05 & 7.3 & 0.73 & 1.30 & 0.117 & 16.84 \\
\hline 8 & 35.30 & 625 & 8.7 & 1.1 & 7.1 & 0.755 & 1.39 & 0.135 & 18.11 \\
\hline 9 & 34.58 & 640 & 8.5 & 1 & 7 & 0.737 & 1.51 & 0.128 & 16.64 \\
\hline 10 & 32.90 & 656 & 8.6 & 1 & 6.9 & 0.767 & 1.40 & 0.132 & 16.58 \\
\hline 11 & 32.21 & 662 & 8.2 & 1 & 6.7 & 0.744 & 1.55 & 0.125 & 16.45 \\
\hline 12 & 31.76 & 670 & 8 & 0.95 & 6.1 & 0.701 & 1.85 & 0.129 & 15.79 \\
\hline 13 & 30.53 & 681 & 7.9 & 1 & 6 & 0.682 & 1.72 & 0.125 & 15.69 \\
\hline 14 & 29.10 & 695 & 8 & 0.95 & 6.1 & 0.685 & 1.90 & 0.128 & 15.79 \\
\hline 15 & 27.03 & 711 & 7.8 & 0.9 & 5.6 & 0.675 & 2.04 & 0.124 & 15.04 \\
\hline 16 & 26.80 & 728 & 7.6 & 0.9 & 5.3 & 0.631 & 2.09 & 0.115 & 14.43 \\
\hline 17 & 24.55 & 740 & 7.1 & 0.95 & 5 & 0.617 & 2.17 & 0.121 & 14.03 \\
\hline 18 & 23.77 & 755 & 6.8 & 0.9 & 4.5 & 0.584 & 2.17 & 0.130 & 12.01 \\
\hline 19 & 20.47 & 765 & 6.6 & 0.85 & 4.4 & 0.603 & 2.40 & 0.133 & 17.76 \\
\hline 20 & 19.43 & 775 & 6 & 0.8 & 3.6 & 0.571 & 3.12 & 0.140 & 10.86 \\
\hline 21 & 12.63 & 785 & 5.2 & 0.75 & 3.3 & 0.579 & 2.82 & 0.144 & 8.38 \\
\hline 22 & 9.71 & 810 & 3.9 & 0.65 & 2.1 & 0.457 & 3.05 & 1.134 & 4.82 \\
\hline
\end{tabular}

Explanatory notes to Tables 4 and 5: $\mathrm{A}_{\mathrm{w}}\left[\mathrm{km}^{2}\right]$ : watershed area; $\varphi \mathrm{H}_{\mathrm{w}}$ [amsl]: mean altitude of the watershed; $\mathrm{W}_{\mathrm{bkf}}[\mathrm{m}]$ : width of the RCS inside the banks; $\mathrm{D}_{\mathrm{bkf}}[\mathrm{m}]$ : mean depth of the RCS; $\mathrm{A}_{\mathrm{bkf}}\left[\mathrm{m}^{2}\right]$ : RCS area; S [m/m]: energy gradient; $\mathrm{R}_{\mathrm{bkf}}[\mathrm{m}]$ : hydraulic radius of $\mathrm{RCS} ; \mathrm{D}_{50}[\mathrm{~m}]$ : grain diameter; $\mathrm{Q}_{\mathrm{bkf}}\left[\mathrm{m}^{3} / \mathrm{s}\right]$ : bankfull discharge. 
Table 5. Geometric and hydraulic characteristics of RCS - Mútňanka

\begin{tabular}{|c|c|c|c|c|c|c|c|c|c|}
\hline No. $\mathrm{RCS}$ & $\mathrm{A}_{\mathrm{w}}$ & $\mathrm{H}_{\mathrm{w}}$ & $\mathrm{W}_{\text {bkf }}$ & $\mathrm{D}_{\text {bkf }}$ & $\mathrm{A}_{\text {bkf }}$ & $\mathrm{R}_{\text {bkf }}$ & $\mathrm{S}$ & $\mathrm{D}_{50}$ & $\mathrm{Q}_{\text {bkf }}$ \\
\hline 1 & 29.93 & 789 & 15.20 & 1.20 & 12.00 & 0.771 & 0.73 & 0.180 & 23.51 \\
\hline 2 & 26.13 & 802 & 14.30 & 1.10 & 12.51 & 0.830 & 0.60 & 0.150 & 20.37 \\
\hline 3 & 24.72 & 807 & 12.10 & 1.00 & 9.04 & 0.722 & 0.77 & 0.155 & 15.85 \\
\hline 4 & 16.43 & 814 & 8.50 & 0.90 & 6.25 & 0.669 & 1.05 & 0.140 & 11.34 \\
\hline 5 & 15.32 & 818 & 9.90 & 0.85 & 5.89 & 0.579 & 1.25 & 0.155 & 11.86 \\
\hline 6 & 14.92 & 826 & 9.50 & 0.80 & 5.82 & 0.588 & 1.27 & 0.130 & 11.45 \\
\hline 7 & 8.92 & 834 & 8.20 & 0.80 & 4.60 & 0.539 & 2.02 & 0.160 & 11.05 \\
\hline 8 & 8.82 & 841 & 8.40 & 0.75 & 4.56 & 0.489 & 1.77 & 0.162 & 9.17 \\
\hline 9 & 6.82 & 845 & 8.20 & 0.70 & 4.02 & 0.472 & 1.48 & 0.152 & 7.58 \\
\hline 10 & 6.70 & 854 & 6.20 & 0.65 & 3.03 & 0.454 & 1.29 & 0.125 & 5.09 \\
\hline 11 & 6.20 & 863 & 6.10 & 0.60 & 2.74 & 0.423 & 2.22 & 0.176 & 5.23 \\
\hline 12 & 5.99 & 871 & 6.30 & 0.65 & 2.93 & 0.430 & 2.05 & 0.220 & 5.34 \\
\hline 13 & 5.79 & 877 & 6.20 & 0.65 & 2.85 & 0.435 & 1.54 & 0.185 & 4.81 \\
\hline 14 & 5.23 & 889 & 5.70 & 0.70 & 3.11 & 0.506 & 1.90 & 0.202 & 5.81 \\
\hline 15 & 4.17 & 904 & 5.90 & 0.65 & 2.61 & 0.424 & 1.91 & 0.191 & 4.96 \\
\hline 16 & 4,01 & 913 & 5.40 & 0.60 & 2.53 & 0.437 & 2.11 & 0.210 & 4.40 \\
\hline 17 & 3.40 & 926 & 4.60 & 0.55 & 1.76 & 0.365 & 2,26 & 0.222 & 3.06 \\
\hline 18 & 3.23 & 937 & 4.30 & 0.50 & 1.53 & 0.333 & 2.07 & 0.183 & 2.44 \\
\hline 19 & 2.09 & 965 & 4.00 & 0.50 & 1.45 & 0.335 & 2.09 & 0.153 & 2.40 \\
\hline 20 & 1.18 & 992 & 3.70 & 0.45 & 1.04 & 0.268 & 2.73 & 0.162 & 1.83 \\
\hline 21 & 1.09 & 1012 & 4.00 & 0.50 & 1.67 & 0.355 & 1.21 & 0.220 & 2.34 \\
\hline 22 & 0.70 & 1037 & 2.80 & 0.50 & 0.84 & 0.279 & 3.44 & 0.240 & 1.67 \\
\hline
\end{tabular}

Explanatory notes to Tables 4 and $5: \mathrm{A}_{\mathrm{w}}\left[\mathrm{km}^{2}\right]$ : watershed area; $\varphi \mathrm{H}_{\mathrm{w}}$ [amsl]: mean altitude of the watershed; $\mathrm{W}_{\mathrm{bkf}}[\mathrm{m}]$ : width of the RCS inside the banks; $\mathrm{D}_{\mathrm{bkf}}[\mathrm{m}]$ : mean depth of the RCS; $\mathrm{A}_{\mathrm{bkf}}\left[\mathrm{m}^{2}\right]$ : RCS area; $\mathrm{S}[\mathrm{m} / \mathrm{m}]$ : energy gradient; $\mathrm{R}_{\mathrm{bkf}}[\mathrm{m}]$ : hydraulic radius of $\mathrm{RCS} ; \mathrm{D}_{50}[\mathrm{~m}]$ : grain diameter; $\mathrm{Q}_{\mathrm{bkf}}\left[\mathrm{m}^{3} / \mathrm{s}\right]$ : bankfull discharge.

Table 6. Regression equations for analyzed relations

\begin{tabular}{|c|c|}
\hline $\begin{array}{c}\text { Correlation } \\
\text { relation }\end{array}$ & $\begin{array}{l}\text { Regression } \\
\text { equation }\end{array}$ \\
\hline$W_{b k f(H)}=f\left(A_{w H}\right)$ & $W_{b k f(H)}=1.0343^{*}\left(A_{w H}\right)^{0.6023}$ \\
\hline$D_{b k f(H)}=f\left(A_{w H}\right)$ & $D_{\text {bkf(H) }}=0.2755^{*}\left(A_{\mathrm{wH}}\right)^{0.3721}$ \\
\hline$A_{b k f(H)}=f\left(A_{w H}\right)$ & $A_{b k f(H)}=0.3288^{*}\left(A_{w H}\right)^{1.0712}$ \\
\hline$Q_{\text {bkf }(H)}=f\left(A_{w H}\right)$ & $Q_{b k(H)}=0.7797^{*}\left(A_{w H}\right)^{0.8818}$ \\
\hline$W_{b k f(M)}=f\left(A_{w M}\right)$ & $\mathrm{W}_{\mathrm{bkf(M)}}=2.7660^{*}\left(\mathrm{~A}_{\mathrm{wM}}\right)^{0.4778}$ \\
\hline$D_{\text {bkf(M) }}=f\left(A_{w M}\right)$ & $D_{\text {bkf(M) }}=0.4078^{*}\left(A_{w M}\right)^{0.2869}$ \\
\hline$A_{b k f(M)}=f\left(A_{w M}\right)$ & $A_{\text {bkf(M) }}=0.6645^{*}\left(A_{w M}\right)^{0.8482}$ \\
\hline$Q_{b k f(M)}=f\left(A_{w M}\right)$ & $Q_{\text {bkf(M) }}=1.3287^{*}\left(A_{w M}\right)^{0.8202}$ \\
\hline
\end{tabular}

Explanatory notes to Tab. 6: $\mathrm{W}_{\mathrm{bkf}(\mathrm{H})}, \mathrm{D}_{\mathrm{bkf}(\mathrm{H})}, \mathrm{A}_{\mathrm{bkf}(\mathrm{M})}$, $\mathrm{Q}_{\mathrm{bkf}(\mathrm{M})}$; bankfull characteristics (Hučava); $\mathrm{W}_{\text {bkf(M)}}, \mathrm{D}_{\text {bkf(M) }}$, $\mathrm{A}_{\mathrm{bkf}(\mathrm{H})}, \mathrm{Q}_{\mathrm{bkf}(\mathrm{M})}$; bankfull characteristics (Mútňanka); $\mathrm{A}_{\mathrm{wH}}$ - watershed area Hučava; $\mathrm{A}_{\mathrm{wM}}-$ watershed area Mútňanka.

relation to the increasing watershed area - significantly steeper development compared to the Hučava torrent bed with a higher geomorphological rock value (rock resistance) of the watershed.

[Wolock et al., 2004] divided the USA into 20 HLRs on the basis of similar natural characteristics, of which the geological bedrock plays a very important role. Other authors [Vianello and D'Agostino, 2007] evaluated the variations in bankfull cross-sections along a steep stream in dolomites (Northern Italy). The relations between watershed area $\mathrm{A}_{\mathrm{w}}$ (from 0.040 to $7.084 \mathrm{~km}^{2}$ ) and bankfull width of the channel inside the banks $\mathrm{W}_{\text {bkf }}$ (from 0.35 to $5.10 \mathrm{~m}$ ) were evaluated with $\mathrm{R}^{2}=0.620$. The relations between watershed area $\mathrm{A}_{\mathrm{w}}$ and channel mean depth $\mathrm{D}_{\mathrm{bkf}}$ (from 0.11 to $0.81 \mathrm{~m}$ ) were evaluated with $\mathrm{R}^{2}=$ 0.49. [Pšida, 2014] evaluated the relationships of the bankfull regional hydraulic geometry in four geographic regions - geomorphologic units in the SR with different bedrocks, whose bankfull characteristics medians displayed the following values: $A_{w}=18.81\left(\mathrm{~km}^{2}\right), \mathrm{W}_{\text {bkf }}=8.10(\mathrm{~m})$, $\mathrm{D}_{\text {bkf }}=0.83(\mathrm{~m}), \mathrm{A}_{\mathrm{bkf}}=4.53\left(\mathrm{~m}^{2}\right), \mathrm{Q}_{\mathrm{bkf}}=8.02\left(\mathrm{~m}^{3} \cdot \mathrm{s}^{-1}\right)$ and the coefficients of determination in relations to the watershed area ranged between $\mathrm{R}^{2}=0.723$ and $\mathrm{R}^{2}=0.977$. The author confirmed the variations in the development of the natural geometric and hydraulic characteristics of torrent beds and their long-term morphogenesis in watersheds with different bedrocks. [Galia and Hradecký, 2014] evaluated 120 bankfull cross-sections of 
Table 7. Statistical testing of the correlation relations

\begin{tabular}{|c|c|c|c|c|c|c|c|}
\hline $\begin{array}{c}\text { Correlation } \\
\text { relation }\end{array}$ & $\mathrm{R}$ & $\mathrm{R}^{2}$ & $S_{R}$ & $\mathrm{t}$ & $\begin{array}{l}> \\
=\end{array}$ & $t_{0,01(22)}$ & RMSE \\
\hline$W_{\text {bkf }(H)}=f\left(A_{w H}\right)$ & 0.981 & 0.962 & 0.044 & 22.3 & $>$ & 2.819 & 0.30 \\
\hline$D_{b k f(H)}=f\left(A_{w H}\right)$ & 0.951 & 0.905 & 0.069 & 13.8 & $>$ & 2.819 & 0.04 \\
\hline$A_{b k f(H)}=f\left(A_{w H}\right)$ & 0.976 & 0.953 & 0.048 & 20.3 & $>$ & 2.819 & 0.42 \\
\hline$Q_{b k f(H)}=f\left(A_{w H}\right)$ & 0.965 & 0.932 & 0.058 & 16.6 & $>$ & 2.819 & 1.11 \\
\hline$W_{b k f(M)}=f\left(A_{w M}\right)$ & 0.971 & 0.943 & 0.053 & 18.3 & $>$ & 2.819 & 0.82 \\
\hline$D_{b k f(M)}=f\left(A_{w M}\right)$ & 0.955 & 0.912 & 0.066 & 14.5 & $>$ & 2.819 & 0.06 \\
\hline$A_{b k f(M)}=f\left(A_{w M}\right)$ & 0.978 & 0.958 & 0.046 & 21.3 & $>$ & 2.819 & 0.69 \\
\hline$Q_{b k f(M)}=f\left(A_{w M}\right)$ & 0.977 & 0.954 & 0.048 & 20.4 & $>$ & 2.819 & 1.32 \\
\hline
\end{tabular}

Explanatory notes to Tab. 7: R: index of correlation; $\mathrm{R}^{2}$ : index of determination; $\mathrm{S}_{\mathrm{R}}: \sqrt{\frac{1-\mathrm{R}^{2}}{\mathrm{n}-2}} ; \mathrm{t}: \frac{\mathrm{R}}{\mathrm{S}_{\mathrm{R}}}$; RMSE: root mean square error.

Table 8. Testing of statistical significance of differences between absolute and relative coefficients in correlation relations

\begin{tabular}{|c|c|c|c|c|c|c|c|}
\hline $\begin{array}{l}\text { Correlation } \\
\text { relation }\end{array}$ & $a_{0}$ & $a_{1}$ & $\mathrm{~s}_{\mathrm{a} 0}$ & $\mathrm{~s}_{\mathrm{a} 1}$ & $\mathrm{t}_{\mathrm{a}}\left(t_{r}\right)$ & $\begin{array}{l}> \\
=\end{array}$ & $\mathrm{t}_{0,05(40)}$ \\
\hline$W_{b k f(H)}=f\left(A_{w H}\right)$ & 1.0343 & 0.6023 & 0.1122 & 0.0313 & 7.307 & $>$ & 2.021 \\
\hline$W_{b k f(M)}=f\left(A_{w M}\right)$ & 2.7660 & 0.4778 & 0.2088 & 0.0283 & 2.952 & $>$ & 2.021 \\
\hline$D_{b k f(H)}=f\left(A_{w H}\right)$ & 0.2755 & 0.3721 & 0.0281 & 0.0297 & 3.815 & $>$ & 2.021 \\
\hline$D_{b k f(M)}=f\left(A_{w M}\right)$ & 0.4078 & 0.2869 & 0.0203 & 0.0203 & 2.368 & $>$ & 2.021 \\
\hline$A_{b k f(H)}=f\left(A_{w H}\right)$ & 0.1462 & 1.1031 & 0.0359 & 0.0699 & 5.149 & $>$ & 2.021 \\
\hline$A_{b k f(M)}=f\left(A_{w M}\right)$ & 0.6645 & 0.8482 & 0.0940 & 0.0478 & 8.798 & $>$ & 2.021 \\
\hline$Q_{b k f(H)}=f\left(A_{w H}\right)$ & 0.7797 & 0.8818 & 0.1829 & 0.0672 & 2.080 & $>$ & 2.021 \\
\hline$Q_{b k f(M)}=f\left(A_{w M}\right)$ & 1.3287 & 0.1893 & 0.8202 & 0.0484 & 0.745 & $<$ & 2.021 \\
\hline
\end{tabular}

Explanatory notes to Tab. 8: $\mathrm{t}_{\mathrm{a}}=\frac{\left|a_{01}-a_{02}\right|}{\sqrt{s_{a 01}^{2}+s_{a 02}^{2}}} ; t_{r}=\frac{\left|a_{11}-a_{12}\right|}{\sqrt{s_{a 11}^{2}+s_{a 12}^{2}}} ;$

$\mathrm{t}_{\mathrm{a}}$ - test characteristic for the absolute coefficient ;

$t_{r}$ - test characteristic for the relative coefficient.

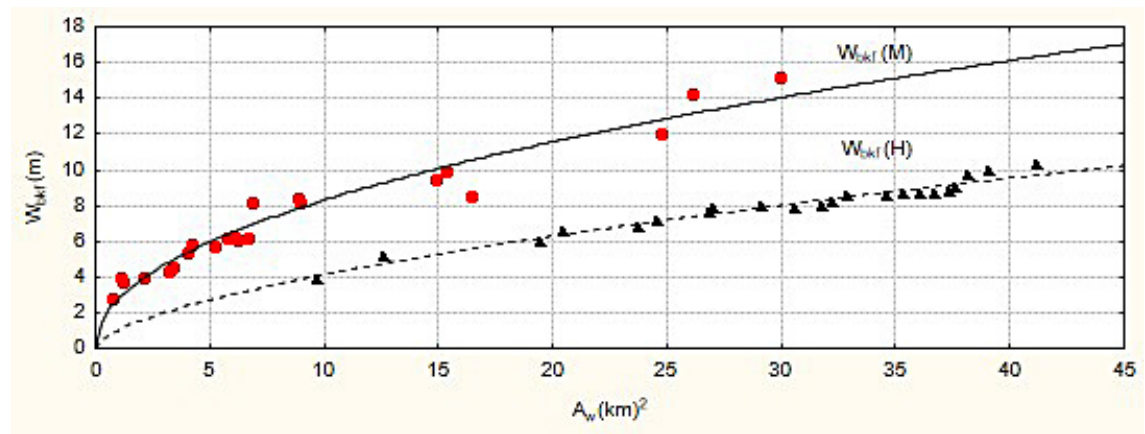

Figure 2. Relations between $\mathrm{A}_{\mathrm{w}}\left(\mathrm{km}^{2}\right)$ and $\mathrm{W}_{\mathrm{bkf}}(\mathrm{m})$

14 mountain streams in flysch bedrock of Outer Western Carpatians in the relations between watershed area (A from $0.45 \mathrm{~km}^{2}$ to $2.59 \mathrm{~km}^{2}$ ), width of the channel inside the banks ( $\mathrm{W}_{\mathrm{bkf}}$ from $2.17 \mathrm{~m}$ to $3.96 \mathrm{~m})$ and mean channel depth $\left(\mathrm{D}_{\mathrm{bkf}}\right.$ from 0.23 to $0.30 \mathrm{~m}$ ). The observed reaches showed a fairly good correlation $\left(\mathrm{R}^{2}=0.53\right)$ between increasing $\mathrm{A}_{\mathrm{w}}\left(\mathrm{km}^{2}\right)$ and $\mathrm{W}_{\mathrm{bkf}}(\mathrm{m})$. By contrast, bankfull mean depth $\mathrm{D}_{\mathrm{bkf}}(\mathrm{m})$ indicated its independence on increasing watershed area $\mathrm{A}_{\mathrm{w}}\left(\mathrm{km}^{2}\right)$ with $\mathrm{R}^{2}=0.03$. [Blackburn - Lynch et al., 2017] reported the results of regional equations from 2856 sites for 


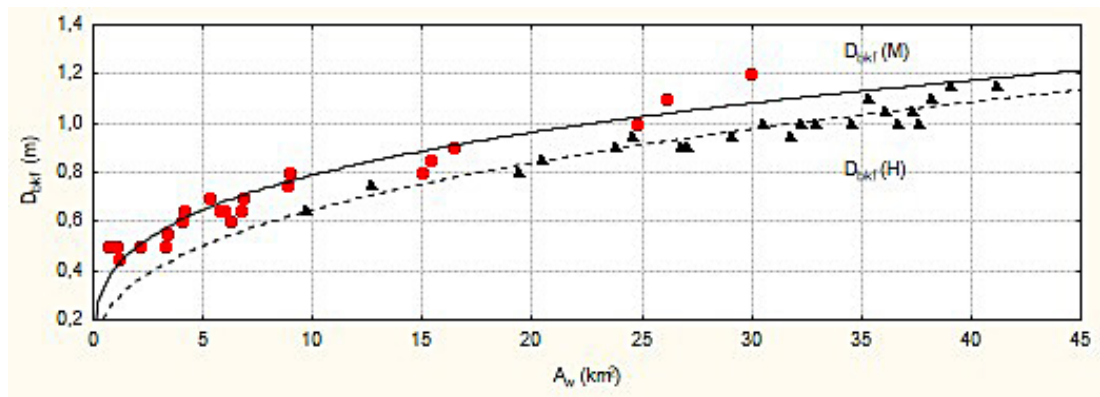

Figure 3. Relations between $\mathrm{A}_{\mathrm{w}}\left(\mathrm{km}^{2}\right)$ and $\mathrm{D}_{\text {bkf }}(\mathrm{m})$

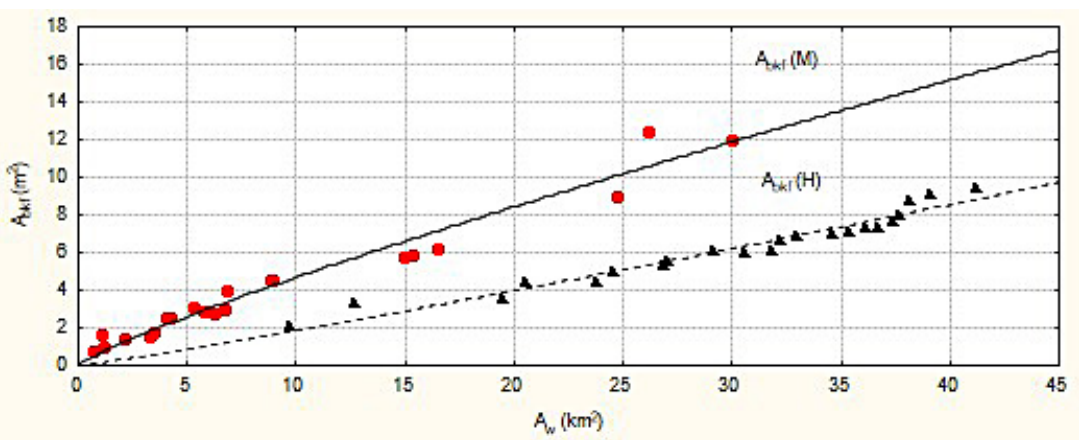

Figure 4. Relations between $\mathrm{A}_{\mathrm{w}}\left(\mathrm{km}^{2}\right)$ and $\mathrm{A}_{\mathrm{bkf}}\left(\mathrm{m}^{2}\right)$

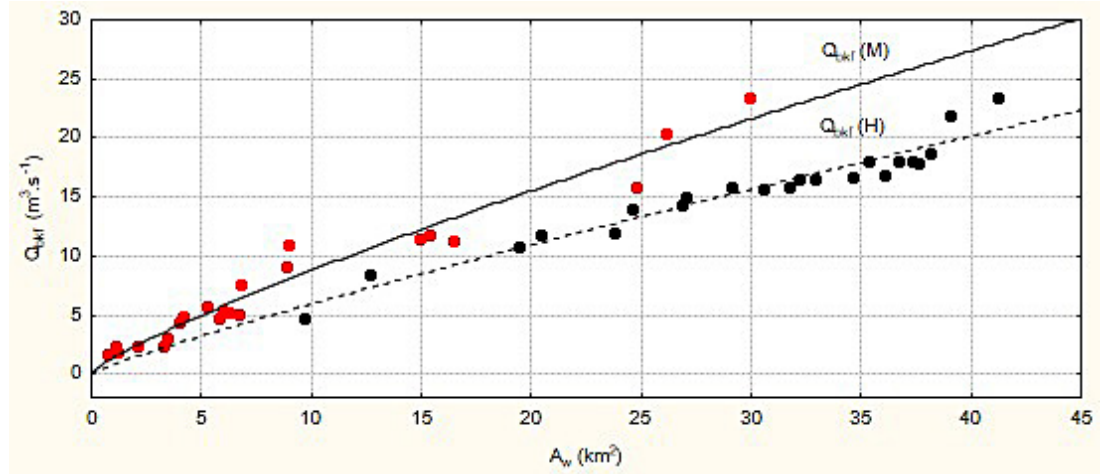

Figure 5. Relations between $\mathrm{A}_{\mathrm{w}}\left(\mathrm{km}^{2}\right)$ and $\mathrm{Q}_{\mathrm{bkf}}\left(\mathrm{m}^{3} / \mathrm{s}\right)$

20 various HLRs in the contiguous USA with the medians of characteristics $A_{w}=71.2\left(\mathrm{~km}^{2}\right)$, $\mathrm{W}_{\mathrm{bkf}}=10.5(\mathrm{~m}), \mathrm{D}_{\mathrm{bkf}}=0.7(\mathrm{~m}), \mathrm{A}_{\mathrm{bkf}}=7.0\left(\mathrm{~m}^{2}\right)$ and $\mathrm{Q}_{\mathrm{bkf}}=19.5\left(\mathrm{~m}^{3} \cdot \mathrm{s}^{-1}\right)$. The coefficients of determination in relations to the watershed area varied from $\mathrm{R}^{2}=0.410$ to $\mathrm{R}^{2}=0.710$. The authors confirmed (i) the importance of research of the regional hydraulic geometry, (ii) the development of relationships between watershed area $\mathrm{A}_{\mathrm{w}}\left(\mathrm{km}^{2}\right)$ and $\mathrm{W}_{\mathrm{bkf}}$ (m), $\mathrm{D}_{\text {bkf }}(\mathrm{m}), \mathrm{A}_{\mathrm{bkf}}\left(\mathrm{m}^{2}\right), \mathrm{Q}_{\mathrm{bkf}}\left(\mathrm{m}^{3} \cdot \mathrm{s}^{-1}\right)$ and (iii) the differences between the regional equations and curves of hydraulic geometry for various HLRs of the USA with various geologic bedrock. Different results are attributable to specific natural features of each geologic region [Powel et al., 2004].

\section{CONCLUSIONS}

Our research confirms that the regional hydraulic geometry equations provide reliable results only for specific geologic regions and can be used in practice only in the regions of data origination. The derived specific regional curves and equations enable a valuable input into the process of ecological designing and torrent control dimensioning, into flood and erosion control and torrent revitalization, especially in large-scale protected areas, with the simultaneous gradual HLRs creation in the SR or as an example of a procedure to deal with these tasks in other countries. 


\section{Acknowledgements}

This article was supported by the Grant Agency KEGA of the Ministry of Education, Science, Research and Sport of the Slovak Republic within the project No. 006TU Z-4/2018: 3-D functional models of landscape flood protection objects as new methods and forms of university education.

\section{REFERENCES}

1. Badman, T. 2010. World Heritage and Geomorphology. In: Migoń, P. [ed.] Geomorphological Landscapes of the World. Dordrecht, Heidelberg, London, New York: Springer Science+Business Media, 357-368.

2. Blackburn-Lynch W., Agouridis C.T. and Barton, CH.D. 2017. Development of Regional Curves for Hydrologic Landscape Regions (HLR) in the United States. Journal of the American Water Resources Association, 53, 903-928.

3. Bieger, K.H., Rathjens, H., Allen, P.M. and Arnold, J.G. 2015. Development and evaluation og bankfull hydraulic geometry relationships for the physiographic regions of the United States. Journal of the American Water Resources Association, 51, 842-858.

4. Composite Authors 2002. Landscape Atlas of the Slovak Republic [In Slovak: Atlas krajiny Slovenskej republiky]. Bratislava, Ministry of Environment of the SR, Banská Štiavnica, Esprit.

5. Costa-Casais, M., Alves, C.M.I. and Blanco-Chao, R. 2015. Assessment and Management of the Geomorphological Heritage of Monte Pindo (NW Spain): A Landscape as a Symbol of Identity. Sustainability, 7, 7049-7085.

6. Dobos, A. and Gali, Z. 2010. Geological and Geomorphological Values of the Castle Hill. Geological and Educational Trail situeted in Szanda (Northern Hungary). Thessaloniki, Greece: Scientific Annals, School of Geology, Aristotle University of Thessaloniki Proceedings of the XIX. CBGA Congress, Special volume, 100, 453-458.

7. Dzurovčin, L. 2000. Geomorphology [In Slovak: Geomorfológia]. Prešov, Prešovská univerzita v Prešove.

8. Franke, W.A. 2018. Durability and conservation of stone: coping with complexity. Journal of Engineering Geology and Hydrogeology, 46, 367-375.

9. Galia, T. and Hradecký, J. 2014. Morphological patterns of headwater streams based in flysch bedrock: Examples from the Outer Western Carpathians. Catena, 119, 174-183.

10. Gleason, C.J. 2015. Hydraulic geometry of natural rivers: A review and future directions. Progress in Physical Geography, Earth and Environment, 39(3), 337-360.

11. Charlton, R. 2008. Fundamentals of Fluvial Geomorphology. London, New York: Routledge.

12. Klimaszewski, M. 1981. Geomorphology [In Polish: Geomorfologia]. Warszawa, Wydawnictwo naukowe PWN.

13. Lacika, J. 1999. Geomorphology. [In Slovak: Geomorfológia]. Zvolen, Technical University in Zvolen.

14. Leopold, L.B., Wolman, M.G. and Miller, J.P. 1995. Fluvial Processes in Geomorphology. New York: Dover Publications Inc.

15. Lindqvist, J. E., Åkesson, U., Malaga, K., Schouenborg, B. and Göransson, M. 2003. Assessment of mechanical durability properties of rock materials using quantitative microscopy and image analysis. SP Report 2003:6 Building Technology and Mechanics. Boras: SP Sveriges Provnings- och Forskningsinstitut, SP Swedish National Testing and Research Institute.

16. Marko, F., Reichwalder, P., Jablonský, J. and Vojtko, R. 2007. Geological mapping. Methods of field geological research. [In Slovak: Geologické mapovanie. Metódy terénneho geologického výskumu]. Bratislava, Univerzita Komenského v Bratislave.

17. Michaeli, E. 2001. Georelief of the Hornad basin. [In Slovak: Georeliéf Hornádskej kotliny]. Geografické práce, IX(2), Prešov, Prešovská univerzita v Prešove.

18. Page, K. J. (1988): Bankfull discharge frequency for the Murrumbidgee River, New South Wales. In: Warner R. F. [ed.], Fluvial geomorphology of Australia. Sydney, Academic Press: 267-281.

19. Parker, G. 2010. The Gravel River Bankfull Discharge Estimator. Minneapolis, University of Minnesota, National Center for Earth-surface Dynamics.

20. Powel, R.O., Miller, S.J., Westergard, B.E., Mulvihill, CH.I., Baldigo, B.P., Gallagmer, A.S. and Starr, R.R. 2004. Guidelines for Surveying Bankfull Channel Geometry and Developing Regional Hydraulic - Geometry Relations for Streams of New York State. U. S. Geological Survey Open File Report 03-92. New York, Troy.

21. Pšida, J. 2014. The research of regional hydraulic geometry of torrent channels in selected geomorphologic units of the SR [In Slovak:Výskum regionálnej hydraulickej geometrie bystrinných korýt vo vybraných geomorfologických celkoch SR]. [Ph.D. Thesis.] Zvolen, Technical University in Zvolen, Faculty of Forestry.

22. Radecki-Pawlik, A. 2002. Bankfull discharge in mountain streams: theory and practice. Earth Processes and Landforms, 27, 115-123. 
23. Radecki-Pawlik, A. 2014. Hydromorphology of rivers. Selected Parts. [In Polish: Hydromorfologia rzek i potoków górskich. Dzialy wybrane]. Krakow, Wydawnictwo Uniwersytetu Rolniczego.

24. Reynard, E. and Brilha, J. 2018. Geoheritage. Assessment, Protection and Management. Amsterdam, Elsevier Inc.

25. Rosgen D.L. and Silvey, H.L. 1996. Applied River Morphology. Pagosa Spring, Wildland Hydrology.

26. Rosgen, D.L. 2009. Watershed assessment of River Stability and Sediment Supply. Fort Collins, Colorado: Wildland Hydrology.

27. Rowiński, P., and Radecki-Pawlik, A. [eds.] 2016. Rivers- Physical, Fluvial and Environmental Processes. Heidelberg: Springer.

28. Sládek, I. 2014. The development of wiews on the geomorphological rock value in Slovak geomorphological literature. [In Slovak: Vývoj názorov na geomorfologickú hodnotu hornín v slovenskej geomorfologickej literatúre]. Geomorphologia Slovaca et Bohemica 14(2), 7-14.

29. Tinkler, K.J. and Wohl, E.E. 1998. A primer on bedrock channels. In: Tinkler K.J. and Wohl, E.E. [eds.] Rivers over Rock: Fluvial Processes in Bedrock
Channels. Geophysical Monograph Series, Washington DC: American Geophysical Union, 1-18.

30. Valtýni, J. 1981. The contribution to classification of torrent and torrent control in Slovakia [In Slovak: Príspevok k triedeniu bystrín a bystrinných úprav na území Slovenska]. Lesnícky časopis, 27, 35-47.

31. Vianello, A. and D'Agostino, V. 2007. Bankfull width and morphological units in an alpine stream of the dolomites. Geomorphology 83, 266-281.

32. Weiyan, G., Jianghai, L., Xiang, M. and Hongguang L. 2013. Geological and Geomorphological Value of the Monogenetic Volcanoes in Wudalianchi National Park, NE China. Geoheritage, 5(2), 73-85.

33. Wohl, E.E. 1998. Bedrock channel morphology in relation to erosional processes. In: Tinkler, $\mathrm{K}$. J. and Wohl, E.E. (eds.): Rivers over Rock: Fluvial Processes in Bedrock Channels. Geophysical Monograph Series, Washington DC: American Geophysical Union,131-151.

34. Wolock, D.M., Winter, T.C. and Mc. Mahon, G. 2004. Delineation and Evaluation of Hydrologic Landscape Regions in the United States using GIS Tools and Multivariate Statistical Analyses. Environmental Management, 34, 71-88. 